Dr NIKOLA ŽUTIĆ, naučni savetnik

Instituta za savremenu istoriju

UDK 323.1(497.1)"1918/1935"

Beograd, Trg Nikole Pašića 11

32:929 Бартуловић Н.

\title{
NIKO BARTULOVIĆ I SLOVENAČKI JUGOSLAVENI 1918-1935*
}

\begin{abstract}
APSTRAKT: $U$ članku se rekonstruiše fenomen jugoslavenstva u zapadnim rimokatoličkim krajevima Kraljevine Jugoslavije, koji svoj korijen vuče od dalmatinske i slovenačke revolucionarne nacional-liberalne projugoslavenske omladine, od koje se u Kraljevini SHS formiraju integralno jugoslavenske organizacije ORJUNA, jugoslavenskih Sokola, Jadranske straže i jugoslavenskih četnika.
\end{abstract}

Ključne riječi: književnik Niko Bartulović, Dalmacija, Slovenija, Srbija, Jugoslavija, Jugoslaveni, Orjuna, Sokoli, Jadranska straža, Četnici, liberali, Književni jug

\section{BARTULOVIĆ - LIBERALNI JUGOSLAVENSKI REVOLUCIONAR 1912-1918.}

Nikola (Niko) Bartulović, filozof, književnik i publicista, rođen je 23. decembra 1990. u Starom Gradu na Hvaru u staroj dalmatinskoj rimokatoličkoj porodici, a tokom vremena nacionalno je „evoluirao" u hrvatsko jugoslavenstvo. Osnovnu školu završio je u Starom Gradu da bi, po želji roditelja, upisao rimokatoličku teološku školu. Gimnaziju je završio u Splitu, u kojem je zajedno s književnicima Tinom Ujevićem i Vladimirom Čerinom radio na stvaranju nacional-liberalnog revolucionarnog jugoslavenskog pokreta. Od 1909. do 1912. studirao je na filozofskim fakultetima u Pragu i Gracu. Poslije završetka studija radio je kao nastavnik gimnazije (gimnazijski suplent) u Kotoru, u kojoj je predavao italijanski jezik i književnost. Iz gimnazije je odstranjen 1913. zbog svoje antiaustrijske političke opredjeljenosti, pa odlazi u Split i radi kao urednik omladinskih revolucionarnih (jugoslavenskih) listova. ${ }^{1}$

\footnotetext{
${ }^{*}$ Rad je deo projekta Srpsko društvo u jugoslovenskoj državi u 20. veku - Između demokratije i diktature (177016) koji finansira Ministarstvo prosvete, nauke i tehnološkog razvoja Republike Srbije.

${ }^{1}$ Opširnije: N. Žutić, Niko Bartulović rimokatolik četnik - od liberala antiklerikalca i antikomuniste do ravnogorca antifašiste, Beograd 2010.
} 
Svoj revolucionarni nacional-liberalizam Bartulović je iskazao ličnim primjerom, aktivnošću u organizacijama jugoslovenske nacionalističke omladine. Kao aktivni učesnik antiaustrijskog omladinskog pokreta imao je viziju ostvarenja jugoslavenskog liberalnog bratstva na razvalinama AustroUgarske. Omladinski liberalni jugoslavenski pokret („naprednjački“), po njemu, začinjao se u književnom stvaralaštvu, i to naročito kritičkim člancima u periodici. Najpozitivnija tekovina „naprednjačkog“ omladinskog pokreta, u borbi protiv ekskluzivnog srpstva i hrvatstva, jeste „srpskohrvatska sloga i jedinstvo", isticao je Bartulović. ${ }^{2}$

Pod uticajem jugoslavenskih liberalnih strujanja iz Dalmacije, od oktobra 1912. u Ljubljani je počeo da izlazi organ „jugoslovenske napredne omladine“ - Preporod, list „skrajno nacionalistički i integralno jugoslovenski“ orijentisan, naročito od 1913. kada je iz naslova izbacio riječ „napredni“. Oko lista su se okupili pjesnik Oton Župančič, August Jenko, dr Ivan Oražen, Vladislav Fabjančič, koji je još kao gimnazijalac bio jedan od pokretača tog jugoslavenskog nacional-liberalnog lista. Predstavnici Preporoda odlazili su u Dalmaciju radi dogovora sa književnicima Čerinom, Ujevićem i Bartulovićem.

Od Srba i Hrvata s Preporodom su najviše sarađivali Bartulica, Bartulović, Mitrinović i drugi. List je izlazio samo godinu dana, jer je ukinut zbog stalnih austrijskih zabrana. Nasljedio ga je slovenački Glas Juga. Iz skupine „preporodovaca" potekli su Slovenci August Jenko, koji je poginuo na Ceru kao dobrovoljac u srpskoj vojsci, zatim Ivan Endliher (Endlicher), koji je umro u tamnici u Gracu, kao i Janže Novak i drugovi koji su takođe bili utamničeni i gonjeni u Austriji. ${ }^{3}$

U julu 1913. u Splitu su se sastali Ujević, Čerina, Bartulović, Tartalja i drugi jugoslavenski nacionalisti oko pitanja pokretanja novog glasnika Glasa Juga, kao nasljednika „Preporoda“. Zaključeno je da su najpovoljnije prilike za izdavanje u Ljubljani, pa je tamo kao delegat otputovao mladi književnik Niko Bartulović. Sa izdavanjem lista se opet kasnilo, pa se izlaženje glasila oteglo sve do 1914. godine. Rat je, međutim, obustavio njegovo preštampavanje u posebnu knjigu. Redakciju splitske Slobode, koju je u jesen 1913. napustio Oskar Tartalja, preuzeo je početkom 1914. Niko Bartulović, i to nakon što su mu austrijske vlasti oduzele mjesto nastavnika gimnazije u Kotoru. I Sloboda je išla „čisto nacionalističkim putem“. Apsolutizam i teror „poznatog oružnika“ Silvaša (Szilvasa) žestoko je udarao na Slobodu i Zastavu, ali su one „neustrašivo" radile u istom jugoslavenskom pravcu. Pored vodećih nacionalista u Splitu (Tartalje, Bartulovića i Čulića),

\footnotetext{
${ }^{2}$ N. Bartulović, Od revolucionarne omladine do Orjune, Split 1925, 9.

${ }^{3}$ 25-godišnjica Preporoda, Krug, br. 5, 5. mart 1938.
} 
braća Anđelinovići - Grgur, Danko i Berislav - aktivno su radili u nacionalističkoj štampi. ${ }^{4}$

Jugoslavenski nacionalistički program je sam po sebi izazivao reakciju i protuakciju Beča, uz pomoć „reakcionarnih“ frankovačkih i klerikalnih elemenata "kod kuće“. Zato je novi namjesnik Dalmacije, grof Atems, poslat u Zadar u sporazumu sa slovenačkim klerikalcem dr Šušteršičem, zatim sa krugovima oko klerikalnog splitskog Dana i sa vođom „klerikalnih pravaša“ dr Dulibićem. Svi su oni zajedno pod motom odbrane od „bezbožnog i liberalnog jugoslavenstva“ spasavali tobož „ugroženo“ katoličko hrvatstvo. U isto vreme „eksponent“ Konrada fon Hecendorfa, splitski okružni načelnik Silvaš, potpomognut od navedenih „reakcionarnih elemenata", zaveo je režim terora "protiv čitavog nacionalnog Splita“, i naročito protiv jugoslavenske nacionalne štampe, zavođenjem oštre cenzure. Treba istaći da je Bartuloviću nekoliko mjeseci ranije bilo oduzeto mjesto nastavnika kotorske gimnazije, „po denuncijaciji reakcionara iz Ljubljane“, zato što su se njegovi rukopisi našli u Preporodu, zabranjenom ljubljanskom jugoslavenskom nacionalističkom listu.

"Nacionalistička štampa“ pokretana je u 1914. i mimo Splita i Dalmacije "kao nikad dotad“. Prvog marta Čerina u Zagrebu pokreće Vihor, list za nacionalističku kulturu, a prije toga, u januaru, publicista Milan Marjanović pokrenuo je na Rijeci Književne novosti, literarnu reviju ali u „čisto nacionalističkom duhu". Koncem marta počeo je Milan Marjanović u Zagrebu izdavati veliki politički sedmičnik Narodno jedinstvo. To nije bio omladinski list, ali su omladinci (Bartulica, Bartulović) u njemu vrlo živo sarađivali. Početkom aprila 1914. napokon je počeo izlaziti Glas Juga (broj za mart) u Ljubljani u formi mjesečne revije. Prema Bartulovićevom zapažanju, naslovna ilustracija je simbolički prikazivala kako južni vjetar nosi austrijskim diplomatama zastarjele puške i šešire. U programatskom uvodniku prvog broja Slovenac Jenko je tražio „stvaranje slobodne i potpuno nezavisne i ujedinjene jugoslovenske nacije“. List je zbog takvih napisa poslije drugog broja zabranjen, a urednici zatvoreni. U isto vreme u Zagrebu je počeo da izlazi nacionalistički omladinski list Nova riječ. U Pragu je 1. maja 1914. izašao prvi broj praške Jugoslavije, sa uvodnikom splitskog publiciste Ljube Leontića, u kome je isticao da se problem Južnih Slavena, i kulturni i politički, može i mora riješiti evolucijom ili revolucijom, milom ili silom - samo u jugoslavenskom smislu.

U tom trenutku sve misli jugoslavenskih omladinskih nacionalista bile su usmjerene na Vidovdanski kongres u Beču i Sveslovenski sokolski slet u Ljubljani, koji je bio predviđen za avgust 1914. godine. Jugoslavenski nacionalisti, prema kazivanju Bartulovića, vrlo živo su agitirali za taj slet jer

\footnotetext{
${ }^{4}$ Isto.
} 
su i oni sami činili jezgro antiaustrijskog jugoslavenskog sokolskog pokreta. Napadi habzburških vlasti su ponajviše bili usmjeravani na srpsko-hrvatsko-slovenačko sokolstvo kao liberalni nacionalno-oslobodilački pokret, koji je tjelovježbom pokrivao svoj pravi cilj - oslobođenje i ujedinjenje južnoslavenskih zemalja $u$ jednu celinu. Progoni jugoslavenskih sokola naročito su se pojačali u vrijeme aneksione krize 1908. godine. U insceniranim „veleizdajničkim procesima“ uvijek su se prozapadni liberalni i antidinastički sokoli nalazili na optuženičkim klupama zbog rada na odvajanju južnoslavenskih zemalja od Monarhije i njihovom priključenju Kraljevini Srbiji.

Svi pomenuti jugoslavenski nacionalistički omladinski listovi agitirali su za sazivanje Vidovdanskog kongresa „ujedinjenja“ u Beču 1914. godine. Na kongres su pristizali delegati „sa svih univerza“ i „iz svih krajeva Otadžbine“. Glavni organizatori kongresa bili su Ljubo Leontić, Vasa Stajić, Špiro Soldo, Mirko Kosić, Krulj, Šukrija Kurtović, Auer, Niko Bartulović i drugi. Za sve njih ,jugoslovensko ujedinjenje je bilo gotova stvar“, pa se na kongresu samo raspravljalo o metodama i programu rada. Glavni motiv je bio da se „iskoristi momenat i požuri sa slomom Monarhije“. Trebalo je „požuriti u sukob“. Sukob je, međutim, već istog dana kucao na vrata pošto je u Sarajevu ubijen Franc Ferdinand, koji je bio inkarnacija težnje za ekspanzijom Austrije i germanstva na istok. On je, prema Bartulovićevoj procjeni, bio „intimni prijatelj sa Vilimom (Viljemom), mrzio je Srbe i Jugoslovenstvo pa je upotrebljavao slovenački i hrvatski klerikalizam za širenje separatizma. Osim toga, bio je agresivan, bahat i energičan, pa je njegov dolazak na vlast mogao da znači najveću pogibelj za jugoslovenska nastojanja". 5

Ubistvo prestolonasljednika Franca Ferdinanda označilo je masovna hapšenja, utamničenja i likvidacije atentatora, jugoslavenskih nacionalista, ponajviše Sokola. Frankovačka, klerikalna i muslimanska štampa u Bosni harangirala je protiv Srba i omladine, rušeno je i pljačkano sve što je srbsko, izvođen je nečuven teror. Bartulović je hroničarski zapisao: „Gdjegod je bio uhvaćen kakav Srbin, naročito omladinac, bio je najpre premlaćen, a onda uapšen. Najmračniji tipovi, pod zaštitom generala Potioreka i nadbiskupa Štadlera, izvodili su ta razbojstva... Ni u drugim pokrajinama nije bilo bolje. U Zagrebu, frankovci, isto tako pod zaštitom policije, demoliraju srpske dućane i napadaju na nacionaliste... Uapšenja se provode naročito $u$ provinciji, u Sremu, Lici i Baniji, a isto tako i u Vojvodini. U Ljubljani i Sloveniji je još gore... Kad je došlo do atentata, Šušteršičevi klerikalci baciše se sa krvoločnim žarom na omladinu, a policija stade da redom zatvara sve što

\footnotetext{
${ }^{5}$ N. Bartulović, Od revolucionarne omladine do Orjune, 41.
} 
se u omladini isticalo. Jenko i Vladislav Fabjančič bili su već u Srbiji i za njima je izdana teralica...". 6

U samom Splitu, na prvi dan mobilizacije zatvoreno je oko 200 ljudi, ,sve gotovo intelektualaca i nacionalnih vođa, a među tima velik broj omladinaca“. Osim Bartulovića i Anđelinovića, koji su već bili u zatvoru, uhapšeni su i zatvoreni Oskar Tartalja, Jerko Čulić, književnik Ivo Andrić („koji se onda desio u Splitu“), Jozo Šegvić i drugovi. U Dubrovniku su zatvoreni dr Frano Kulišić, M. Đenero i drugovi; u Zadru Mirko Korolija, A. Filipić i drugovi; na Hvaru Rudolf Đunio, dr Vjerko Vranican i drugovi; u Šibeniku Grgo Čičin Šain, Frane Perica „i sva sila drugih“. .

Bartulović i ostali uhapšeni su prvo bili u zatvoru u Splitu, pa potom u Šibeniku. Poslije mjesec dana prevezeni su brodom do Rijeke, pa potom željeznicom preko Zagreba, Budimpešte, „pa opet natrag“ preko Prekomurja u Maribor. Bartulović je zapisao: „Taj strašni put trajao je četiri dana, bez hrane i bez sna, i svuda smo na mađarskim štacijama bili dočekani kao srpski zarobljenici, sa demonstracijama i kamenjem...". U Mariboru su uz omladince bili i dr Ante Tresić Pavičić, dr Josip Smodlaka, dr Ivo Tartalja, dr Prvislav Grisogono, dr Milko Čingrija, dr Mate Drinković i mnogi drugi. Nakon jedne godine sudilo im se u Gracu. Osuđeni su gotovo samo članovi nacionalističke omladine: Maja Čulić-Nižetić na tri godine, Jerko Čulić (Majin suprug), dr Anđelinović na dvije godine, dok su Niko Bartulović, Oskar Tartalja i Antun Farčić dobili čak pet godina robije. Optužnice su podignute radi „veleizdaje i uvrede Veličanstva, počinjene širenjem velikosrpske propagande, te radi bunjenja i nastojanja da se zemlje u kojima živu Južni Sloveni, otrgnu od jedinstvenog sklopa Austrougarske monarhije".

Početkom jula 1917. došlo je do opće amnestije političkih krivaca, pa je Bartulović poslije tri godine robije pušten na slobodu. Njemu i ostalim oslobođenim nije bilo dozvoljeno da se vrate u Dalmaciju, već su, pošto su svi bili teško bolesni, prebačeni u bolnicu Milosrdnih sestara u Zagrebu, koja je postala „središte nacionalističke omladine“. ${ }^{8}$ S približavanjem kraja rata jugoslavenska nacionalistička omladina se ponovo pokušavala okupiti. Vršila se aktivna propaganda jugoslavenstva, te se demonstriralo protiv Austrije. Vođene su u Zagrebu i humanitarne akcije, npr. akcija spasavanja gladne srpske i hrvatske djece iz Bosne i Dalmacije, koja je uz humani imala i „odlučni nacionalistički cilj“, pa su u njoj učestvovali i omladinci Jerko Čulić, R. Matulić, Bujas, Anđelinović, Niko Bartulović i drugi.

\footnotetext{
${ }^{6}$ Isto, 45-47.

${ }^{7}$ Isto, 51.

${ }^{8}$ Isto, 51-53, 71.
} 


\section{Jugoslavenski književni pokret, Književni jug i Bartulović 1918. godine}

Prvo glasilo koje je počelo da okuplja jugoslavensku mlađu nacionalnu inteligenciju bila je Hrvatska (Jugoslavenska) njiva, koju je osnovao Juraj Demetrović, pa potom i Hrvatska riječ, (kasnije Riječ), koja je „pisala smiono" pod uredništvom S. Parmačevića, kome je kasnije prišao i Niko Bartulović. „Starčevićanci“ (frakcija „milinovaca“) s vremenom su se, od isključivog hrvatstva, sve više orijentisali prema jugoslavenstvu. Oni su početkom 1918. osnovali novi časopis Hrvatsku državu, čije su uredništvo preuzeli dr Budislav G. Anđelinović i Niko Bartulović, te joj dali „izraziti revolucionarni i jugoslovenski smjer“, pa su zbog toga bili „najviše od cenzure proganjani“. Godine 1918. počeo je da izlazi i list Srđana Budisavljevića i Valerijana Pribićevića Glas Srba, Hrvata i Slovenaca, koji je „zastupao revolucionarno jugoslovenstvo“, i u kojem su sarađivali „omladinci“, naročito Vladimir Ćorović, Ivo Andrić, Jovo Miodragović i drugi. ${ }^{9}$

$\mathrm{U}$ isto vreme Niko Bartulović, „u društvu sa omladincima“ Ivom Andrićem, dr Vladimirom Ćorovićem i Brankom Mašićem, osnovao je reviju Književni jug, oko koje je „okupio svu nacionalnu literaturu“. Književni jug se u stvari javio kao knjiški i kulturni propagator jugoslavenske integracije neposredno prije propasti Austro-Ugarske. Stvarni pokretač i glavni urednik Književnog juga bio je Niko Bartulović. Književni jug, prema zapažanju Bartulovića, „kao prvi je opet uveo u upotrebu zabranjenu ćirilicu“, prvi je publikovao „srbijanske pisce“ i „smiono“ isticao jugoslavenstvo i narodno jedinstvo kao cilj svog rada. Kao i u svim jugoslavenskim „nacionalističkim“ listovima, zbog dužnog poštovanja prema oslobodilačkoj Srbiji, prilozi su objavljivani ekavskim narječjem srpskog jezika.

Književni jug je u stvari bio prva revija na Slavenskom jugu koja je s uspjehom počela praktički da „polaže čvrste i solidne temelje budućoj velikoj jugoslovenskoj književnosti“. Bartulović je sa zadovoljstvom konstatovao da je „ona već do sada okupila oko sebe sve što je od vrednosti, nakon trogodišnjih patnja i iskušenja“, i sve što je „ostalo nacionalno, zdravo i nerastrovano". ${ }^{10}$

Kulturni program jugoslavenskih nacionalista imao je za cilj da na prvo mjesto stavi „veliku ideju Sokratovu: Spoznaj samog sebe“, odnosno spoznaj svoj narod, u njemu traži izvor snage, veličinu duha, iz njega stvaraj svoju samoniklu kulturu. ${ }^{11}$ Prema Juraju Demetroviću, jugoslavenski

\footnotetext{
${ }^{9}$ Isto.

${ }^{10}$ Riječ urednika Nike Bartulovića, br. 3-4, 16. februar 1918.

${ }^{11}$ J. Demetrović, O sadržini našeg nacionalizma, Jugoslavenska njiva, br. 2, januar
} 1923, 51. 
nacionalizam nije bio samo predratni omladinski pokret, koji može i treba da bude samo jedan njegov ogranak. Jugoslavenski nacionalizam morao je ići u širinu, odnosno, jugoslavenski nacionalisti su morali biti i državnici i umjetnici i privrednici i socijalni radnici, ,a nada sve jugoslavenski sokoli, jer je sadržina jugoslavenskog nacionalizma i jugoslavenskog sokolstva potpuno ista i treba da bude ista. Pa kad jednom dođe do historijskog obračuna, do kojeg mora doći, onda će da triumfira pobjednička i kao krv crvena košulja (sokolska karbonarska - N. Ž.) nad crnom košuljom mraka (klerikalnom rimokatoličkom - N. Ž.)! I jedinstvo jugoslavensko tad će biti gotovo". Kao ortodoksni jugoslavenski nacionalista Bartulović je u potpunosti bio saglasan sa Demetrovićevim liberalnim vizijama jugoslavenstva, koje se $\mathrm{u}$ svom začetku pominjalo $\mathrm{u}$ formi kulturnog (duhovnog) jedinstva troimenog jugoslavenskog naroda, pa tek potom u formi državnopravnog ostvarenja te romantičarske ideje. Književni jug je pozivao na saradnju pisce najraznolikijih sredina. Odbacivao je podjelu literature prema zavičajnim listovima pisaca, kao izrazitu regionalističku pojavu i cijeneći svoje izlaženje kao "jugoslovenski poduhvat",

Književni jug je u 1918. imao postojanu strukturu rubrika logično uređenih i raspoređenih, u kojima su svoje radove objavljivali eminentni književnici, istoričari i publicisti različitog profila ali i različitog ideološkog opredjeljenja. Osim srpsko-hrvatskih pisaca i pjesnika za Književni jug su pisali najbolji slovenački književnici Oton Župančič i Ivan Cankar. Članke književno-istorijskog karaktera, vezano za Sloveniju, pisali su Niko Bartulović ( „Kulturno jedinstvo i Slovenci“, „Slom civilizacije“, „Politička sloboda i kultura“), Janko Glaser, dr Fran Ilešić („Jezik u nacijonalnom razvoju Slovenaca“, „Petar Preradović v Slovencih“), Anton Loboda („Za kulturno zedinjenje Jugoslovanov"), dr Branko Vodnik i drugi. U rubrici „Pregled“ (prikazi i kritike knjiga) pisao je i Niko Bartulović o slovenačkim stvaraocima („Ljubljanski zvon“, „Dom in Svet“, „Slovan“), o dr Branku Vodniku i drugima.

U prvom broju od 1. januara 1918. Bartulović je odmah istakao „veru u pobedu narodne stvari“; Vladimir Ćorović je slavio Milutina Bojića, Tresić-Pavičić je „pjevao svog prkosnog Ikara“, Nazorova „Majka Margarita" sjeća se Majke Jugovića, a list reproducira na naslovnoj strani Meštrovića, dok je Ivo Andrić predstavio svoj „Ex Ponto“ ili „Zapise iz zatočenja 1914-1917. godine“.

Kao glavni urednik Bartulović je dao uvodnu riječ o „zadacima vremena“, uz obraćanje čitaocima i saradnicima slijedećom porukom: „Uz novu reviju napisah ovo par misli ne kao program ni kao obećanje, već naprosto kao jedan nevezani poticaj suradnicima i publici na zajednički rad i nastojanje“. Taj članak je bio surova kritika „ratnih klanja“, ali uz nagovje- 
štaj mira i svijetlu nadu ostvarenja jugoslavenskog bratstva, bez obzira na filozofske, kulturološke i političke ideološke razlike. ${ }^{12}$ Bartulović je među prve postavio kulturne i umjetničke zadatke: „Svi oni vode k jedinstvu i slobodi i za te ciljeve ništa nije previsoko. Umjetnost je oslobađanje po sebi i u redovima boraca njeno je mjesto između prvih. Ne radi se tu o nacionalizmu kao novinarsko-patriotskoj tendenciji, već o stihijskom aktu oslobađanja snagom, istinom i ljepotom. Jugoslovenska umjetnost mora biti u istinu jugoslovenska, ako će da postane općenita i svjetska“. ${ }^{13}$ U Književnom jugu Bartulović se spisateljski ogledao više na području književne kritike pišući prikaze knjiga i ocjene umjetničke vrednosti pisaca, da bi se s vremenom, „s dolaskom slobode“, sve više opredjeljivao za publicističke radove koji su bili ideološko-političke ili istoriografsko-književne prirode.

Bartulović je, kao i istoričar dr Vladimir Ćorović, u Književnom jugu promovisao „ekavicu“ kao jezički oblik koji će spajati jugoslavenske narode i naročito jačati kulturno jedinstvo jedinstvenog jugoslavenskog naroda. Hrvati - jugoslavenski nacionalisti su, zbog bržeg stapanja (sintetizovanja) jugoslavenskog naroda i odavanja priznanja Srbiji za stvaranje Jugoslavije, popularizirali ekavicu „u interesu jedinstva i književnog i kulturnog i narodnog". Tako su se za ekavicu izjasnili dr Josip Smodlaka, Milan Marjanović, Vladimir Čerina, P. Mitrović, dok su njom „pisali delomično“ Ivo Andrić i „potpuno mlađi elementi“ kao U. Donadini, Kuzma Tomašić, A. Šimić. ${ }^{14}$ Ćorović je zaključio da „ekavštinu" brani velik dio Hrvata" i vrlo mali broj Srba, ali da je ona u suštini slovenačka. On je zadovoljno konstatovao da je „ekavština u glavnom, danas već opšti književni jezik srpskog dela našeg naroda“, ali u dobroj mjeri i slovenačkog i hrvatskog, pa je istakao slijedeće: „Kad se tome doda, da su i Slovenci za to, jedno, jer je ekavština njihova, a drugo jer žele većih koncepcija (F. Ilešić, I. Hribar, N. Županić), i kad to rešenje prima i jedan deo Hrvata, onda ima nade da to može postati i opšti književni jezik Južnih Slovena“. Slovenci F. Ilešić i I. Hribar su navodili da bi za njih ekavština „bila veliko olakšanje u čitanju i govorenju hrvatsko-srpskog jezika“, i to bi bio „sigurno jedan korak u kojem bi Slovenci vidjeli nekakav ustupak svome stanovištu i koji bi mogao usled toga doneti samo dobre posledice $u$ približavanju našeg književnog govora hrvatsko-srpskome s naše strane“. Uvođenjem „istočnog narečja“ kao opšteg jezika u srpsko-hrvatsku književnost, po ocjeni Hribara, ta književnost se približavala slovenačkom jeziku. Hribar je, osim toga, smatrao da je „istočno narečje krepče od južnoga i da mu je i radi toga milije“. Ćoro-

\footnotetext{
${ }^{12}$ N. Bartulović, Zadaci vremena, Književni jug, br. 1, 1. januar 1918.

${ }^{13}$ Isto.

${ }^{14} \mathrm{~V}$. Ćorović, Za književno jedinstvo - pitanje narečja i pisma, Književni jug, br. 3-4,
} 16. februar 1918. 
vić je, dakle, u potpunosti prihvatio ranije Skerlićeve stavove o ekavštini: „U ekavštini je kolijevka (ne kaže „kolevka“) naše pismenosti“; njom se služe skoro svi oni 'što stoje u pročelju naše srpsko-hrvatske literature'; njom govori pretežna većina našeg naroda; njom piše i govori kulturniji deo našeg naroda; 'ijekavski je teško pisati i piše se nedosledno, ekavština je kraća i jednostavnija i tome slično". Marko Car je navodio da Beograd predstavlja književni centar, pa je prirodno da se primi i njegov dijalekat, dok je F. Kulišić podvlačio da ekavštinom piše „sve što je bolje, vrednije i lepše“.

Potpuno su protiv ekavštine, po Ćoroviću, bili Hrvati Frano Supilo, Ivo Vojnović (!), Mile Starčević, R. Katalinić Jeretov i Petar Skok. Supilo je bio za ijekavštinu kao književno nasleđe "najvećih srpskih, hrvatskih i slovenačkih filologa i književnika - Vuka, Miklošića, Jagića, Daničića, Gaja, Vraza itd.“. Supilo je isticao i da ,južno narječje u sebi najbolje sintetizira naše narodno jedinstvo, pošto jedan dobar dio i Hrvata i Srba govori tim narječjem". S druge strane, Srbin rimokatolik Ivo Vojnović se više zalagao za uvođenje gregorijanskog kalendara kao važnijeg faktora za postizanje narodnog jedinstva, od jedinstvenog narječja Srba i Hrvata. ${ }^{15}$

I pored svih više ili manje opravdanih razloga tradicionalista (po Ćoroviću „konzervativaca“) da se zadrže oba narječja, Ćorović je u ime integralnog jugoslavenstva, a radi stvaranja jedne i jedinstvene kulture i književnosti, kruto insistirao na potpunom jezičkom stapanju jugoslavenskog naroda. On je upravo nategnuto forsirao argument u prilog ekavice, da tim narječjem govori većina srpsko-hrvatskog naroda, što nije bila istina, pošto je $\mathrm{u}$ to vreme i zapadna Srbija u dobroj mjeri govorila ijekavski (a u daljoj prošlosti i Karađorđeva i Miloševa Šumadija). U svom sintetičkom jugoslavenskom bezumlju Ćorović nije imao ništa protiv da se zarad liberalnodemokratskog („masonskog“) jugoslavenskog jedinstva ukine i srpska ćirilica, za ljubav Hrvata i Slovenaca. Srbin iz Hercegovine je izrekao jedno prosto neuobičajeno razmišljanje protiv ćirilice: „Gotovo je jednodušna želja Hrvata i Slovenaca, da Srbi napuste ćirilicu i prime pismo, kojim se služe oni i gotovo sav ostali kulturni svet. Mi u stvari, protiv toga ne bi ništa imali. Ćirilica je adoptirano tuđe pismo isto kao što je bila glagoljica i kao što je danas latinica“. U nastavku svog napisa je ublažio svoj „antićirilski“ stav i opravdavao zadržavanje ćirilice u upotrebi.

Bartulović će se u budućnosti u dobroj mjeri držati ovih Ćorovićevih, u suštini Skerlićevih (poznate rasprave o uvođenju jednog ekavskog "narečja“) kompromisnih stavova, da jedan jedinstven jugoslavenski narod koristi ekavicu i u što većoj mjeri latinicu. Zato će Bartulović svoje radove pisati i objavljivati latinicom i ekavskim narječjem. Radi što bržeg stapanja „troplemenog" jugoslavenskog naroda, Bartulovićeva književno-kritička

${ }^{15}$ Isto. 
aktivnost u Književnom jugu kretala se u pravcu „ravnopravnog“ kritičkog prikazivanja srpsko-hrvatsko-slovenačkih časopisa i autora koji su pisali u integralno-jugoslavenskom duhu. Književni jug je postao „centralna jugoslavenska revija".

Kako bi Srbima i Hrvatima prikazao rad na književnom polju kod Slovenaca, Bartulović je napisao obimniji kritički prikaz slovenačkog književnog časopisa Ljubljanski zvon, koji je izlazio od 1881. godine. Pod uredništvom „današnjeg najboljeg slovenačkog pesnika“ Otona Župančiča, Zvon je, po Bartuloviću, „uvijek bio najbolja slovenačka književna revija“ jer je bio "glasilo liberalaca“. ${ }^{16}$ Nasuprot liberalnom Ljubljanskom zvonu, koji je okupljao „naprednu stranu slovenskih književnika“, rimokatoličku ideološku knjišku grupaciju predstavljao je klerikalni Dom in Svet, koji je „zastupao tzv. katoličku skupinu slovenskih književnika", ali, po Bartuloviću, „nipošto nije bio ultramontanski list“, jer je pokazivao „evoluciju u sve liberalnijem i savremenijem smeru“. ${ }^{17}$ Treća slovenska književna revija, koju je kritički prikazao Bartulović, bio je Slovan, glasilo „katoličke skupine slovenskih književnika“, oko kojeg se „kupila jedna skupina mlađih liberalaca“. Ta skupina je bila „najjugoslavenskija“ jer je okupljala „mlade pristaše predratne nacionalističke omladine". ${ }^{18}$

Radi potpunog stapanja „jugoslavenskog naroda“ uredništvo Književnog juga u februaru 1918. odlučilo je da za svoje pretplatnike Srbe i Hrvate izda mali riječnik slovenskog (slovenačkog) jezika. Uredništvo je prigodom te objave u Književnom jugu istaklo da između slovenskog i srpskohrvatskog govora „postoji doduše mala razlika“, ali da „ipak ima reči koje su različite, pa radi njih čitalac nemože da uživa u lepoti dela koje čita“: „Nama je uspelo za saradnju dobiti sve bolje slovenske pisce i čitaoci će nam sigurno biti zahvalni, da im omogućimo tačno razumevanje dela jednog Ivana Cankara i Otona Župančiča u našem listu. Za nekoliko meseci neće im trebati više rečnika, tako će se lepo naviknuti razlikama govora". Za slovenske pretplatnike i one koji ne znaju ćirilicu, uredništvo Književnog juga je obećalo pretplatnicima i zainteresiranim da će štampati ćirilsku abecedu i razaslati je na adrese. ${ }^{19}$

I prije jugoslavenskog ujedinjenja, dakle, Bartulović je pokazivao izuzetnu sklonost ka sjedinjenju "srpskohrvatskog naroda“ sa Slovencima, koji su se ipak u dobroj mjeri jezički i civilizacijski razlikovali od „slavenskih južnjaka“. Kao poticaj što bržem sjedinjenju Slovenaca s ,južnom braćom“, Bartulović je za Književni jug napisao članak „Kulturno jedinstvo i

\footnotetext{
${ }^{16}$ N. Bartulović, Ljubljanski zvon, Književni jug, br. 3-4, 16. februar 1918.

${ }^{17}$ N. Bartulović, Dom in Svet, Književni jug, br. 7, 1. april 1918.

${ }^{18}$ N. Bartulović, Slovan, Književni jug, br. 8-9, 1. maj 1918.

${ }^{19}$ Slovensko-srpskohrvatski rečnik, Književni jug, br. 3-4, 16. februar 1918.
} 
Slovenci“, povodom rasprava u slovenačkoj znanstvenoj i kulturnoj reviji Veda iz 1913, koja je pokrenula anketu o pitanju jugoslavenskog kulturnog, književnog i jezičkog jedinstva. Bartulović je konstatovao da je na tu anketu bio slab odaziv Slovenaca, između ostalog i zbog toga što su pojedini hrvatski književnici i političari smatrali da je „slovenski jezik kao narodno-književni jezik posve suvišan“ (npr. Frano Supilo), da se Slovenci, po njima, „imaju združiti s Hrvatima u jedno nacionalno ime Hrvat, i u jeziku hrvatskome (tako je govorio npr. frankovac Niko Zvonimir Bjelovučić - N. Ž.)“. Bartulović se 1913. odazvao Vedinoj anketi i tada istakao da je problem jugoslavenskog kulturnog jedinstva, „za sve svesne Jugoslavene“ samo problem metode: „Ako stojimo na demokratskom i pravednom stanovištu, te ako smo zaista tako dobri Jugoslaveni, da nam je sve slovensko isto tako milo kao i srpsko-hrvatsko, onda ne može biti ni govora o tome da neko nešto napusti na korist drugoga, a najmanje ime i jezik". ${ }^{20}$

Bartulović je njegovao poseban osjećaj prisnosti prema „bratskom“ slavenskom češko-slovačkom narodu, za koji je očekivao da će se, kao i jugoslavenski narod, u budućnosti stopiti u jedan narod pod liberalno-demokratskom ideološkom zaštitom „zapadnih demokracija“. Junski broj Književnog juga Bartulović i saradnici posvetili su svečanosti „Narodnog divadla“ koja je održana od 15. do 18. maja 1918. u Pragu. „Velebna slava“ u spomen polaganja temeljnog kamena „Narodnog divadla“, pokazala je „do kojeg stupnja se podigla češka dramatska umetnost, češka opera i češka muzika“, ali i do kojeg se „uspela i kako je ojačala česka narodna svest i sav život narodni“. Proslavi 50-godišnjice polaganja temeljnog kamena „Narodnog divadla“ prisustvovalo je uredništvo Književnog juga, koje je bilo „zastupano" od Ive Vojnovića i urednika Nike Bartulovića i Vladimira Ćorovića. Bartulović je izvjestio da je bilo najbrojnije „odaslanstvo iz jugoslavenskih zemalja" sa književnicima Ivom Vojnovićem, Otonom Župančičem, dr Antom Tresićem-Pavičićem i drugima. ${ }^{21}$

Sa sveskom od 1. juna završavalo se pola godine od izlaska prvog broja i prva knjiga Književnog juga. Uprava Književnog juga, na čelu sa Bartulovićem, od „nemogućeg je učinila realnim“ postojanje časopisa, pa je s ponosom konstatovala „da se ne samo dovoljno obeležio u našoj javnosti, nego da je u njoj zauzeo i jedno vidno i značajno mesto“. ${ }^{22}$ U knjizi II Književnog juga Bartulović je objavljivao pjesme u prozi („Maribor 1914“), kritičke prikaze knjiga (Grge Novaka „Pučki prevrat na Hvaru“, dr Dragutina

\footnotetext{
${ }^{20}$ Vidjeti članak o Bartulovićevoj Vedinoj anketi iz 1913, kao i njegov članak „Kulturno jedinstvo i Slovenci“ (Književni jug, br. 7, 1. april 1918).

${ }^{21}$ N. Bartulović, Svečanosti Narodnog divadla u Pragu, Književni jug, br. 10-11, 1. juni 1918.

${ }^{22}$ Književni jug, 1. jun 1918.
} 
Prohaske „O pjesniku slobode“ - studije o književnom radu Ive Vojnovića povodom njegove 60-godišnjice, „Dve univerzalne biblioteke“, „Tri česka jubileja“ - o trojici čeških književnika Otokaru Brezini, Jaroslavu Kvapilu i Ruženi Svobodi, kao i druge radove).

Na inicijativu Nike Bartulovića krajem oktobra 1918. objavljen je Veliki kalendar Književnog juga za 1919, u saradnji sa Odborom SHS žena za siročad. Objavljivanje knjige imalo je humanitarni karakter, zbog prikupljanja materijalnih sredstava za Odbor, kome su bila neophodna za zimsku odjeću i obuću za 18.000 djece, „koje nam već do sada naš seljak ishranjuje“. U „bogatom opsegu“ kalendar je donosio radove „ponajboljih“ kulturnih radnika i umjetnika, „potresan uvodnik“ Ive Vojnovića, „lepe pesme“ Alekse Šantića, Ante Tresića-Pavičića, Ive Andrića, novele i pripovjetke Svetozara Ćorovića, Milice Janković, Branka Mašića i drugih, preglede srpske i hrvatske književnosti dr Vladimira Ćorovića i Nike Bartulovića, te savremene „poučne“ članke Vase Stajića, Juraja Demetrovića, dr Alekse Ivića, dr Ive Tartalje, Milana Kašanina i drugih. Kalendar je oštampan u jugoslavenskom lingvističkom duhu - srpskohrvatskom latinicom i srbskom ćirilicom i na slovenačkom jeziku. ${ }^{23}$

Prvo godište Književnog juga završilo se trobrojem od 15. decembra 1918. Uredništvo je rezimiralo proteklu godinu ispunjenu radom, borbom, žrtvama, uspjesima, ,jer je započeta u ropstvu a završena u slobodi“. Sve se to desilo u vremenu kada je „sve ćutalo i strepilo od straha i nade, kad je naše ujedinjenje bilo još daleko u magli budućnosti, kad je i samo naše pismo bilo zazorno". Uredništvo se ponosilo činjenicom da je Književni jug skromnim sredstvima podigao „nikad neizneverenu misao narodnog ujedinjenja“, i izneo „ceo niz književnih imena za koja se mislilo da su mrtva i raspršena“. U te teške dane Književni jug je nastojao da „oblagorodi duše koje čekaju i stradaju, i da im učvrsti veru u pobedu, koja je evo i došla... Delo započeto u robovanju nastavićemo i u slobodi“. ${ }^{24}$ Povodom ostvarenja toliko čekane slobode od jugoslavenskog naroda, a naročito od jugoslavenskih nacionalista, Bartulović je napisao članak „Politička sloboda i kultura““ ${ }^{25}$

Bartulović je kao glavni urednik nastojao da okupi sve najznačajnije jugoslavenske pisce, i u tome je u velikoj mjeri uspio. $\mathrm{O}$ tome je $\mathrm{u}$ „Reči urednika“ zapisao slijedeće: „Prvi pisci sa čitavog Juga, u koliko ih je preostalo, okupljaju se još neprestano oko Književnog juga; i svaki novi broj naše revije nije nego, sem najmlađih, novi niz poznatih i dragih nam imena iz svih naših krajeva. Kad se još uzmu u obzir, s jedne strane neprilike, nestašice i svemoguće zapreke i ometanja strahovitog ovog doba u kom živimo, a

\footnotetext{
${ }^{23}$ Književni jug, 1. novembar 1918.

${ }^{24}$ Književni jug, 15. decembar 1918.

${ }^{25}$ Politička sloboda i kultura, Književni jug, knj. II, sv. 10-12, 15. decembar 1918.
} 
s druge strane, požrtvovnim radom poverenika i prijatelja, neverovatni odziv čitavog jugoslovenskog naroda, onda možemo laka srca reći - da smo već sada stali čvrsto na noge. Ali to je tek početak; i ma koliko nam borba bila draga, i ma koliko nas mladost nosila, rad opajao i pratile nas simpatije - to ipak još nije dostatno. Ne samo našim poverencima, znancima i prijateljima, nego i našim pretplatnicima dužnost je, da se zauzmu za nas, da našu reviju i naše edicije prošire što više među svojim ljudima. Samo tako moguće nam je onda u punom razmahu poleta dati punu meru onoga, što se od nas očekuje". ${ }^{26}$

Publicista Vladislav Fabjančič (Bučka 1894 - Ljubljana 1950), nekadašnji pokretač i urednik Preporoda, ostao je na jugoslavenskoj nacionalnoj liniji i u vremenu izlaženja Književnog juga, pa je zbog takvog nacionalnog opredjeljenja postao i saradnik tog jugoslavenskog lista. Prethodno se kao dobrovoljac u srpskoj vojsci borio na Ceru 1914, učestvovao u propagandnom radu Jugoslavenskog odbora u Rimu, a do 1918. radio je u presbirou Ministarstva inostranih poslova Kraljevine Srbije u Ženevi, gdje je ujedno dovršavao svoje $u$ Beču započete romanističke studije. O Fabjančičevom dosljednom integralno jugoslavenskom opredjeljenju svjedoči njegovo pismo "g. profesoru“ (najvjerovatnije radikalu dr Lazaru Markoviću) od 13. decembra 1918. godine. „G. Profesoru“ je izražavao zahvalnost za njegovo držanje „u pogledu unutrašnjeg uređenja naše države“, jer je i sam uvijek bio mišljenja da jugoslavenska država, „pošto smo samo jedan narod“, mora biti unitaristička. Država je, po Fabjančiču, i iz drugih razloga morala biti unitaristička: „Danas opažamo da se baš najkonzervativniji elementi i bivši besni austrijanci izjavljuju za svakojake federacije. Na nama Srbima i Slovencima stoji, kao i na Dalmatincima i trezvenim Hrvatima, da, uprkos razornih elemenata, ostvarimo i sačuvamo slobodu, jedinstvo i budućnost naše nacije. Sav moj rad kod kuće biće upućen jedinstvu, i taj rad nije težak, jer ogromna (možda skoro svi) većina (podvukao V. F.) Slovenaca jesu toliko politički zreli da znaju da bez jedinstva cele naše rase nema ni veličine, ni budućnosti, ni demokratije. Možda se nećemo slagati u svim pojedinostima, ali u glavnom ćemo se složiti: jedinstvo. Od jakobinske revolucije nije ostalo ništa drugo do unitarizma, ali taj je ostao. Ja ću svima snagama raditi za jedinstvo, jer znam da je to i u duhu i u koristi i u željama Slovenaca. Kao što sam dosad pogodio mišljenje slovenačkih masa, ubeđen sam da se i ovog puta ne varam“. ${ }^{27}$ Marković je "g. Profesora ovlastio „za svaku upotrebu ovog pisma“.

${ }^{26}$ Književni jug, br. 3-4, 16. februar 1919.

${ }^{27}$ AJ, Zbirka Lazara Markovića, f. 1, dok. 3, 13. decembar 1918. 


\section{DALMATINSKI JUGOSLAVENSKI INTEGRALISTI I SLOVENAČKI ORJUNAŠI I ČETNICI 1922-1935.}

Bartulović i dalmatinski Jugoslaveni vrlo su kritički nastupili protiv ponašanja novih vlasti, naročito pokrajinskih, u prečanskim, bivšim austrougarskim pokrajinama, zbog odbacivanja iz javnog života predratnih jugoslavenskih nacionalista i stavljanja u prvi plan austrijskih klerikalaca, šuckora, radićevaca, a „bez predstavnika one omladine koja je dala Principa, Čabrinovića, Ilića, Krausa, Jenka i Mikačića“. Po njemu, tzv. prevrat nije bio tako konzumiran, dok su se „dojučerašnji austrijanci uvukli u posao organiziranja mlade države kao trojanski konji, odbacivši od sebe masku jedinstva, počeli otvoreno da provađaju defetističku rabotu na svim linijama“ “ ${ }^{28}$

Nacionalistička omladina se osjećala prevarenom, nastupilo je nejedinstvo, njihovi jugoslavenski ideali nisu bili dovoljno zastupani u realnoj državnoj politici i ideologiji. Zato su Leontić, Bartulović, Đunio, Bartulica i dr Vrsalović, „koji su se našli u Zagrebu“, uvidjeli da „sve te rasparčane omladinske akcije" neće donijeti ploda, i da je jedini put „smiono se nadovezati na bečki Vidovdanski kongres“ iz 1914, i sazvati u Zagrebu „veliki zbor celokupne predratne omladine, i nove, koja se s njom slaže, i na tom kongresu udariti temelje jednoj snažnoj organizaciji i jednom zdravom pokretu, koji će biti raširen po celoj zemlji“. Inicijatori zbora, na čelu s Leontićem i Bartulovićem, održavali su predkonferencije i spremali tehničku stranu kongresa, koji je bio zakazan za septembar 1919. godine. Izdan je i proglas „Poziv na kongres Jugoslavenske ujedinjene omladine u Zagrebu“. Kongres je trebalo biti „svečana manifestacija Jugoslavenstva“, ali na kraju do njegovog održavanja nikad nije došlo, prvenstveno zbog slabe podrške vlasti. U Zagrebu je bilo još nekoliko pokušaja okupljanja omladine, radilo se na jačanju veza sa Splitom i Beogradom (naročito je bio aktivan Bartulović), ali zbog pomanjkanja finansijskih sredstava ništa od svega zamišljenog nije realizovano. ${ }^{29}$

Za svoje ekskluzivne integralno jugoslavenske ideje Leontić i Bartulović nisu imali punu potporu tek osnovane države. Bartulović je, opisujući prve godine Kraljevstva Srba, Hrvata i Slovenaca (SHS), isticao da su prilike u državi „bile sve nesnosnije“, naročito zbog komunizma i „radićevštine“, koja se sve više širila u antidržavnom smjeru. Pater Anton Korošec je, „umjesto Krekovim stopama“ socijalnog katolicizma, pošao putem „ekstremnog klerikalca Šušteršića“, dok je „srpski hegemonizam imao svojih Čokorila“. U tako „burnim i teškim prilikama“, po mišljenju Bartulovića, nije bilo mjesta „sitnom radu“ ni „postepenoj evoluciji“, pa je trebalo bor-

\footnotetext{
${ }^{28}$ N. Bartulović, n. d., 78.

${ }^{29}$ Isto, $78-79$.
} 
beno krenuti pod geslom „protiv unutrašnjeg i spoljnjeg neprijatelja!“, „za državno i narodno jedinstvo!", „za red, auktoritet i snagu Jugoslavije“. ${ }^{30}$

Težak i nesređen položaj Dalmacije, naročito zbog italijanske okupacije, nalagao je stvaranje jedne ekskluzivne integralno jugoslavenske organizacije u Splitu, „koji je uvijek bio žarište jugoslavenstva“. „Nukleus“ buduće "Orjune" bilo je prosvjetno društvo "Svetlo", osnovano 1920, iz kojeg je 23. marta 1921. prvobitno nastala organizacija Jugoslavenske napredne nacionalne omladine, koja je apelirala da se nikako ne dozvoli nekažnjeno vređanje državnog i narodnog jedinstva, kao i „dela stotina hiljada palih junaka". Ona je stalno isticala kontinuitet rada s predratnom nacionalističkom omladinom, i to naročito zbog optužbi da je njena organizacija kopija fašizma.

Na Vidovdan 1921. izišao je prvi broj njihovog glasila pod nazivom Pobeda (simbolički se mislilo na pobjedu Jugoslavenstva i „nacijske afirmacije u svetu"). Pobeda je u početku izlazila kao polumjesečnik pa potom kao nedjeljnik. Pored glavnog organa Pobede, orjunaši su izdavali Vidovdan $\mathrm{u}$ Novom Sadu, Orjunu u Ljubljani, u Skoplju Južnu Zvezdu, u Beogradu Preporod, Princip u Sarajevu, Budućnost u Osijeku, Soču u Šibeniku i Novi Pokret u Vukovaru. „Himnu Orjuni“ spjevao je 15. oktobra 1921. hercegovački srpski nacionalni pjesnik Aleksa Šantić. U Orjuni je aktivno djelovao dalmatinski Srbin dr Mirko Korolija (kasnije je postao i predsjednik); on je napisao pjesmu „Jugana, vila najmlađa“ koja je bila posvećena nacionalnoj omladini i „kojom je 15. oktobra 1921. otvoreno Narodno pozorište u Splitu“, na čelu sa „intendantom“ Nikom Bartulovićem. ${ }^{31}$

Konačno je statutom od 21. maja 1922. naziv Jugoslovenske nacionalno napredne organizacije i zvanično promjenjen u Organizaciju jugoslavenskih nacionalista (Or-Ju-Na). Svrha organizacije bila je da „pomoću svih moralnih intelektualnih, a po potrebi i fizičkih snaga svojih članova bude obrana kulturnih i političkih tekovina, koje je jugoslavenski narod postigao svojim ujedinjenjem; da svojim djelovanjem, iznad svih stranačkih, klasnih ili vjerskih interesa, bilo koje grupacije u državi, podiže i širi u narodu jugoslavensku unitarnu misao i svijest o dužnostima spram zajednice (naroda i države); da energično istupa protiv svakoga rada koji bi mogao da ugrožava osnovne uslove narodne budućnosti: jedinstvo naroda i države; da se bori protiv svih pojava, koje su odraz težnje za separatizmom, plemenskim, pokrajinskim ili vjerskim“ “. ${ }^{32}$ Statut Orjune, koja je pokrivala područje cijele

${ }^{30}$ Isto, 80.

${ }^{31}$ U vreme stvaranja i početnog rada „Orjune“ Niko Bartulović je osnivao Narodno kazalište u Splitu, u kojem je i radio kao upravitelj od 1921. do 1926. godine. Za vreme boravka u Splitu, do odlaska u Beograd 1926, bio je potpredsjednik Direktorija Organizacije jugoslavenskih nacionalista (ORJUNA), a potom u dva sreza bio biran za oblasnog poslanika.

${ }^{32}$ N. Bartulović, n. d., 95-96. 
Kraljevine SHS, odobren je od Ministarstva unutrašnjih dela. Ubrzo su osnovani oblasni odbori u Zagrebu, Sarajevu, Subotici, Beogradu i Ljubljani.

U radu Orjune Niko Bartulović je aktivnije počeo da učestvuje od januara 1923. godine. U aprilu 1923. kooptiran je u Centralni odbor, a aktivno je učestvovao u pripremama Kongresa za 1. decembar 1923, koji je održan na praznik državnog ujedinjenja. Na kongresu je glavni govornik bio dr Mirko Korolija, a govorili su pukovnik Jurišić u ime Šumadije, dr Leontić $\mathrm{u}$ ime Dubrovnika. Među glavnim referentima je bio i Niko Bartulović koji je govorio o „Ideologiji i taktici“. Njegov referat je jednoglasno prihvaćen kao „baza pokreta“, a jednoglasno je prihvaćena i rezolucija kao zaključak iz Bartulovićevog referata. Zbog izuzetnog značaja za ideologiju jugoslavenstva ljubljanski oblasni odbor štampao je Bartulovićev referat u posebnoj brošuri. Poslije uspješnog nastupa na kongresu Bartulović je biran za potpredsjednika novog Direktorija, dok je predsjednik postao dr Ljubo Leontić. ${ }^{33}$

„Orjunu“ je naročito brinuo hrvatski nacionalizam koji se širio i u „najjugoslovenskiji kraj - Dalmaciju“. Zabrinjavalo ih je sve jače prodiranje radićevaca, ali i s druge strane „zvanična i privatna ometanja sa strane nekih radikala, iz čije sredine počinje akcija za osnivanje razbijačkih organizacija"(misli se na Srpsku nacionalnu organizaciju, skraćeno „Srnao" - N. Ž.). Bartulović je u to vreme, s pogledom jugoslavenskog integraliste, pisao da se „javljaju lažni nacionalizmi u svim krajevima, ne samo hrvatski i srpski, nego i katoličko-slovenački i tursko-muslimanski, koji ne zaziru ni od fizičkih pouličnih sukoba“.

Podršku Orjuni pružale su jugoslavenske unitarističke snage, pa tako i jugoslavenske demokrate Ljube Davidovića i Svetozara Pribićevića. Od 1922, Jugoslavenska demokratska stranka je od prvobitno jugoslavenske unitarističke stranke, koja je bila bitan faktor prilikom izglasavanja „centralističkog" Vidovdanskog ustava, počela sve više poprimati dualnu formu podjele na dva krila: Davidovićevo, koje je sve više naginjalo ka jugoslavenstvu troimenoga naroda („realnom jugoslavenstvu“), odnosno sporazumu tri plemena (Srba, Hrvata i Slovenaca); i Pribićevićevo, koje nije htjelo da popusti pred Radićevim (kon)federalizmom i slovenačko-klerikalnim autonomizmom, a koje se i dalje zalagalo za politiku integralnog (nedjeljivog) jugoslavenstva i vladu „čvrste ruke“. To je bilo ishodište za stvaranje unutrašnje političke akcije preko Organizacije jugoslavenskih nacionalista, koju $\mathrm{su}$, dakle, pokrenule Pribićevićeve pristalice u Dalmaciji i pristalice unitariste Gregora Žerjava u Sloveniji, „kjer se ni v ničemer odmaknila od mladoliberalcev in od Pribičevićeve politične linije“ ${ }^{34}$

${ }^{33}$ N. Bartulović, $n$. d., 115.

${ }^{34}$ Prvi junij 1924. v Trbovljah, Stenografski zapisnik kazenske razprave v Celju dne 25, 26. in 27. novembra 1924, Ljubljana 1964, 8-9. 
Bartulović je naročito cijenio orjunaški pokret u Sloveniji, „koji se naglo i sjajno širio" uprkos velikim otporima klerikalaca i slovenačkih autonomista. U Ljubljani se prva organizacija javila već u aprilu 1922, ali je naišla na ogromne zapreke od „separatističkih klerikala, defetističkih komunista, učmalih starijih liberala“, a najviše od državne vlasti. „Žalosne uspomene namesnik Hribar" odbio je četiri puta da im potvrdi pravila, dok ih je, $s$ druge strane, njemačkom političkom društvu odmah potvrdio. U novembru 1922. rekonstruisan je privremeni Odbor, a na predsjedničko mjesto došao je „junački dobrovoljac iz Pivkovog bataljona, agilni i odlučni Marko Kranjec, inžinir". ${ }^{35}$

Poslije sedmomjesečnog djelovanja u Sloveniji, Oblasni odbor Organizacije jugoslovenskih nacionalista počeo je od 1. januara 1923. da izdaje glasilo (nedeljnik) Orjuna - nacionalistični organ. U prvom broj ljubljanske Orjune kao saradnici lista pojavili su se vođa orjunaša inž. Kranjec, „odlični predratni nacionalista" dr I. Lah, pjesnik Peterlin-Petruška, Jurković i drugi. U tom broju ljubljanskog glasila istaknuto je da se Orjuna proširila po cijeloj Jugoslaviji, sa centralnom organizacijom - „Centralnim upravnim odborom" u Splitu i glavnim podružnicama - oblasnim upravnim odborima u Ljubljani, Zagrebu, Novom Sadu, Subotici, Beogradu, Splitu, Sarajevu, Skoplju i Cetinju. Nacionalni cilj Orjune bio je „jedan integralno ujedinjeni Jugoslovenski narod“; ,jedna državu od Crnog mora do 'sinjeg' Jadrana, od Radgone i Celovca do Skadra i Soluna“. ${ }^{36}$ Zbog naglog širenja Orjune u Sloveniji, namjesnik klerikalac Hribar je na sve načine nastojao da se ova organizacija u Sloveniji raspusti.

O počecima Orjune u Sloveniji socrealistički autor je 1964. zapisao slijedeće: „V Sloveniji je 'Or-JU-Na', kakor je razvidno iz njenega glasila, tednika 'Orjuna', ki je začel izhajati v Ljubljani v začetku 1923, močno navezovala na narodnjaško izročilo protinemških in protutalijanskih narodnostnih bojev v preteklosti in na nasprotstvo do klerikalizma, do ostankov avstriakanstva, do nemškega razgovarjanja po ulicah in po javnih prostorih $\mathrm{v}$ mestih, brž pa je prehajala z izvedbo organizacije po fašistovskem zgledu $\mathrm{v}$ teroristično udarno silo zoper vse 'državi sovražne' življe, zoper vse nasprotnike 'integralnega' jugoslovenstva ali 'separatiste', avtonimiste, federaliste, republikance, internacionaliste, ki so ji bili vsi skupaj enako zavrženi 'defetisti' in ki jim je pripravljala z enakimi sredstvi enako usodo, kakšno so priredili fašistovski skvadristi 'anacionalnim' socialistom, komunistom in demokratom v sosednji Italiji“. Klerikalci, hrvatski frankovci i komunisti „orjunaše“ su prozvali „teroristički nacionalisti“ ${ }^{37}$

\footnotetext{
${ }^{35}$ N. Bartulović, $n$. d., 100-101.

${ }^{36}$ Kdo smo in kaj hočemo, Orjuna, Ljubljana, br. 1, 1. januar 1923.

${ }^{37}$ Prvi junij 1924.v Trbovljah...
} 
Bartulović je naročito hvalio uspon slovenačke Orjune u drugoj polovini 1923. godine, pod vodstvom inž. Kranjeca. „Osim junačke borbe protiv separatista i stranih elemenata", slovenačka Orjuna organizirala je i veličanstvene agitacione manifestacije pri blagoslovima svojih barjaka. Poznati slovenački književnik Vladimir Levstik je bio istaknuti član Orjune. Jovica Silobrčić je u ljubljanskoj Orjuni zapisao da jugoslavenski nacionalisti moraju raditi na izgradnji novog tipa čovjeka - Jugoslavena, na stvaranju novog čovjeka, ,jednog čistog jugoslovenskog rasnog tipa“. ${ }^{38}$

Na orjunaše su napadali „svi redom": hrvatski separatisti (hanaovci), srpski nacionalisti (srnaovci), komunisti i klerikalci popa Korošeca. Slovenec je „orjunaše“ prozvao „jugofašistima“, jer su po njemu bili idejni izvor fašizma, sa tvrdnjama da traže inspiraciju u Italiji. ${ }^{39}$ Slovenački „orjunaši“ su odgovarali: „Ali mi imamo glavara doma; nama nije potrebno da molimo kardinala Gasparija, tajnika Sv. Stolice i člana vatikanskega fašija za direktive, kako to radi SLS v pisarni De propaganda fide. U našoj organizaciji nema učlanjenih kardinala“. Slovenec je dalje tvrdio da je Orjuna iz fašizma „posnela paganski element: Morda misli narodnost, ki so jo ideologi klerikalizma proglasili za paganstvo. V tem slučaju bi bilo resnice dasi svoje nacionalnsti ne hodimo šele iskat v Italijo, kakor delajo klerikalci. Če sta narodnost in paganstvo sinonima, potem smo pač pagani, in sleer zagriženi pagani, ki jim je evangelij iz katoliške tiskare nad vse zopern. Glede Danteja, Manzonija in Kavurja, ki jih Slovenec imenuje v eni sapi kot idejne vire fašistov, so Orjunaši - ne samo dalmatinski - bolje poučeni ko Slovenec...". ${ }^{40}$ S druge strane, „orjunaši“ u Sloveniji su nastojali što bliže sarađivati sa jugoslavenskim nacionalistima u Sokolima, Jadranskoj straži, Četnicima, Narodnoj odbrani. „Orjunaši! Pristopajte v Jadransko stražo" - glasio je poziv ljubljanske Orjune od 24. juna 1923. godine.

Prva redovna skupština Oblasnog odbora „Orjune“ za Sloveniju bila je u Ljubljani 25. marta 1923. kada je formiran oblasni odbor na čelu s

${ }_{38}^{38}$ Jovica M. Silobrčić, Jugoslavenski rasni tip, Orjuna, 14. januar 1923.

${ }^{39}$ U jugoslavenskoj istoriografiji i književnoj publicistici o Organizaciji jugoslavenskih nacionalista (Or-juni) se nedovoljno, i pri tom, subjektivno pisalo kao o terorističkom, pa čak i fašističkom pokretu ,jugofašista“. Književni istoričar iz Zagreba Branimir Donat za „Orjunu“ je napisao da je to „nepartijska ali u biti fašistoidna organizacija“, odnosno organizacija kojoj „temelji nisu demokratske naravi te da se u psihologiji sačuvala i dalje njeguje praksu terorizma“. „Orjuna“ je, po Donatu, ostala vezana „uz fantome svoje fašistoidne ideologije“, pa iz Orjunine fašistoidne prošlosti proteže Bartulovićev tobožnji četnički fašizam (B. Donat, Niko Bartulović hrvatski pisac - apologet Orjune i četničke ideologije, Republika, br. 7-8, 1990). Među rijetkim istoriografskim radovima ističemo članak Branislava Gligorijevića o tzv. profašističkim pokretima u Kraljevini Jugoslaviji, u kome je „Orjuna“ kao organizacija integralnih jugoslavena - liberala dobila „totalitarno ideološko obilježje, sa profašističkim prizvukom“. - B. Gligorijević, Osobenosti fašizma u Jugoslaviji dvadesetih godina, Marksistička misao, br. 3, Beograd 1986.

${ }^{40}$ Jugofašizem, Orjuna, Ljubljana, 20. maj 1923. 
predsjednikom inž. Ferdom Kranjecom, potpredsjednikom vojv. Atanazijem Ristićem. ${ }^{41}$ Druga redovna skupština Oblasnog odbora „Orjune“ za Sloveniju održana je u Celju 2. februara 1924. godine. Predsjednik „Orjune“ dr Ljubomir Leontić iz Splita nije mogao prisustvovati skupštini u Celju zbog prisustva sahrani književniku Aleksi Šantiću u Mostaru. Leontić je „davno pre rata sa nezaboravnim slovenskim drugovima stvarao prvo udruženje jugoslovenskih studenata, prvu našu omladinsku Jugoslaviju...". Borili su se za integralni jugoslovenski program, kako je izvještavao list Dubrovnik 7. februara $1924{ }^{42}$

Bartulović je konstatovao da je april 1924. bio vrlo buran za Orjunu. Njen „uspješan rad“ izazivao je stalne ljudske žrtve: u Dubrovniku su "hanaovci“ ubili Franju Siausa, u Tovariševu Tošu Radojčina; u Slavonskom Brodu su komunisti ranili Đorđa Maletića, a u Dubrovniku hanaovci su ranili Đuru Kolendića; u Bitolju u borbi sa kačacima teško je ranjen Mihajlo Reljić. Radi sprečavanja sukoba i odbrane članstva, u Split je krajem aprila došao na dogovor s Direktorijem, „veliki čelnik“ Ilija Trifunović - Birčanin. Prilikom dolaska vojvoda Birčanina i Pećanca u Dalmaciju, Orjuna je držala velike zborove u Splitu, Dubrovniku, pa potom i u Sarajevu, na kojima su, osim njih, govorili Leontić i Bartulović

Najkrvaviji sukob „orjunaša“ desio se sa komunistima prilikom posvete „Barjaka radničke Orjune“ u Trbovlju 1. juna 1924. godine. 0 tom događaju ostavio je snažan i upečatljiv zapis Niko Bartulović: „Komunisti i nemškutari, ljuti što im Orjuna otima ljude baš u radničkom Trbovlju, organiziraju nečuveno zločinstvo. Kad je veličanstvena povorka prolazila mirno ulicama, kličući Jugoslaviji i Kralju, navališe na nju komunisti iz zasede bombama i revolverima, ne imajući obzira ni prema ženama koje su išle $u$ povorci. Odmah padoše mrtvi najbolji naši drugovi u Sloveniji, neumorni i idealni France Šlajpah, magister farmacije, zatim, oblasni čelnik, junački dobrovoljac iz Pivkovog bataljona Stanko Znideršič i barjaktar Orjune $u$ Šiški, mladi i zanosni Žarko Boltavzar. Uza sve žrtve, Orjunaši se ne smetoše, već pod vodstvom predsednika Kranjeca i zagrebačkog oblasnog čelnika Bere Anđelinovića pređoše u obranu i junački rasteraše komunističke zlikovce. U okršaju je bilo ranjeno još nekoliko orjunaša (Lebar, Petrič, Kukec i dr.), a od protivnika pali su 4 mrtva i nekoliko ranjenih. Nad mrtvim našim drugovima izvršen je blagoslov barjaka do kraja, a zatim su žrtve prenesene u Ljubljanu, gde im je priređen pogreb, tako veličanstven, da ga Ljubljana ne pamti sličnog. Oko 20.000 duša je učestvovalo pogrebu, a u ime Direktorija došao je 'Veliki Čelnik' Birčanin. Nad grobovima su govorili Birčanin, Kranjec, Levstik, te predstavnici svih nacionalnih društava. Čitava

${ }^{41}$ Orjuna, 9. februar 1924.

${ }^{42}$ Orjuna, 16. februar 1924. 
nacionalna javnost i štampa ustala je protiv zlikovaca, a u Sloveniji su žrtve donele nove hiljade i hiljade članstva Orjuni. Klerikalci i separatisti nastojali su da obrane ubojice, a u tom im se pridružila na žalost stanovita liberalna štampa, ali su Leontić i Bartulović u dokumentovanim člancima (u 'Politici' i 'Novoj Evropi') potisnuli tu kampanju. Sudska istraga dokazala je najbolje na kome je krivnja, te su komunisti osuđeni, a svi Orjunaši oslobođeni“". ${ }^{43}$

Krvavi događaji u Trbovlju dodatno su razbudili orjunaške organizacije, držani su zborovi i komemoracije poginulima. Zbog događaja u Trbovlju Bartulović je otputovao u Beograd, dok je za 23. juni 1924. u Sarajevu sazvana treća redovna sjednica Glavnog odbora „Orjune“, kojom je predsjedavao Ljubo Leontić. Vidovdan 1924. proslavljen je u mnogim gradovima pod jakim utiskom trbovljanskih nemilih događaja, ali i kao desetogodišnjica "junačkog čina“ njihovog „predratnog druga Principa“. Poslije događaja u Trbovlju proslava u Ljubljani trebalo je da bude i manifestacija orjunaške snage „protiv svih neprijatelja“. U ime Direktorija iz Splita došao je potpredsjednik Niko Bartulović, a iz Zagreba Bere Anđelinović. Na „veličanstvenom zboru" u prisustvu oko 15.000 ljudi govorili su Bartulović, Kranjec, Anđelinović i Ristić. Bartulović je ponovo govorio u Sinju avgusta 1924. prilikom osvećenja orjunaške zastave. U to vreme ministar unutrašnjih dela u Davidovićevoj vladi Nastas Petrović, disident iz Radikalske stranke, naročito je proganjao „Orjunu“, „dočim su Radićevci imali potpunu slobodu“. Hapšeni su orjunaši u Makarskoj, Zagorju, a u septembru je, na zahtjev klerikalaca, uhapšen predsjednik ljubljanske oblasti Marko Kranjec. Potpredsjednik Bartulović je sa Birčaninom i Radojlovićem u nadležnom ministarstvu u Beogradu protestirao protiv zabrane rada pojedinih orjunaških organizacija, pa je kasnije „posveta zastave u Makarskoj bila dozvoljena i uspela veličanstveno". ${ }^{44}$

Organizacija jugoslavenskih nacionalista i dalje je $u$ potpunosti sarađivala sa jugoslavenskim Udruženjem četnika. Ljubljanski list Orjuna je obavijestio da će „Zbor svih mestnih glavarjev ljubljanskega bataljonskega okrožja" biti održan 1924, u petak 18. jula u 8 sati uveče u areni Narodnog doma, a zbor „vseh četnikov" u subotu, dne 19. t. m. „ob 8. uri zvečer" na istom mjestu. ${ }^{45}$ Ljubljanska Orjuna se, potom, na prvoj strani lista, od 8. avgusta 1924, obratila „Braći i sestrama! Četnicima!“ („Bratje in sestre! Četniki!"): „Otkako je prešla vlada u radićevsko-tursko-klerikalne ruke, stremljenje klerikalne politike ide za tim da se uništi Orjuna. Hoće nas

${ }^{43}$ N. Bartulović, $n$. d., 120-121.

${ }^{44} \mathrm{~N}$. Bartulović, $n$. d., 123.

${ }^{45}$ Orjuna, 14. juli 1924. U istom broju objavljen je članak „Klerikalci i Orjuna“, preko cijele prve strane. 
uplašiti s neutemeljenim proganjanjima naših članova. Pokušavaju nam naškoditi sa širenjem lažnih vijesti o skorom raspuštanju organizacije i lopovskim 'obrekovanjem o posameznih članih Oblastnega odbora..." ". 46

Pokrajinski namjesnik, klerikalac Hribar, i dalje je intenzivno proganjao liberalne orjunaše. Ljubljanska Orjuna je objavila vijest da je 17. septembra 1924. „aretiran“ čak i predsjednik Oblasnog odbora „Orjune“ za Sloveniju inž. Marko Kranjec (montirani proces zbog trbovljanske tragedije). Odlučeno je da ga do daljnjeg zamjenjuje „brat" Vladimir Levstik, književnik. Tim povodom Oblasni odbor za Sloveniju pozvao je članstvo i sve organizacije da se, „mirne krvi“ uz četničku pjesmu "Sprem'te se, sprem'te“ i uz poklič „Naprej do konačne zmage“, okupe 21. septembra 1924. i prisustvuju razvijanju „praporja naše vrle organizacije v Zagorju ob Savi pred sokolskim domom". ${ }^{47}$

Šesta redovna sjednica Glavnog odbora slovenačke „Orjune“ održana je 20. marta u Ljubljani, pod predsjedništvom dr Ljube Leontića. Na velikom zboru govorili su Kranjec, Leontić, Bartulović i Edo Bulat. Odbor je na kraju zaključio da se Veliki kongres svih Orjuna održi u Beogradu 31. maja 1925. godine. Niko Bartulović je ispred Direktorija (centrale) Orjune iz Splita bio zadužen da obilazi Sloveniju i propagira antiklerikalnu ideologiju "Orjune“, ali i ideologiju „Jadranske straže“. Prisustvovao je i redovnoj sjednici Glavnog odbora Orjune u Ljubljani 20. i 21. marta 1925. godine. Pored Bartulovića, koji je bio potpredsjednik Glavnog odbora (najavljen i kao „književnik in direktor Pobede za Prestolniško sekcijo Direktorijuma“), Direktorij je u Ljubljanu uputio i predsjednika Glavnog odbora advokata dr Ljubu Leontića; „velikog čelnika“ vojvodu Iliju Trifunovića - Birčanina za oblasni odbor Ljubljana; predsjednika inž. Marka Kranjeca; političkog tajnika Vladimira Levstika za oblasni odbor Maribor; Radivoja Rehara, novinara „in oblastnog čelnika“; odvjetnika dr Irgoliča za oblasni odbor Zagreb; dr Sašu Stulhofera za oblasni odbor Novi Sad; oblasnog tajnika Dobrosava Jevđevića, novinara i upravnika „Vidovdana“; za oblasni odbor Beograda vojvodu Iliju Trifunovića - Birčanina; za oblasni odbor Splita dr Edu Bulata i druge. ${ }^{48}$

Sjednicu Glavnog odbora u Ljubljani otvorio je predsjednik Direktorijuma dr Ljubo Leontić. Poslije iscrpnih referata "brata“ Bartulovića o stanju u Pobedi, „brata“ Levstika o Orjuni i „brata“ Jevđevića o Vidovdanu, usljedila je debata o orjunaškom tisku, pri čemu se sa zadovoljstvom konstatovalo da su svi „organi“ (listovi) znatno napredovali. Na sjednici se dalje vršila „temeljita ideološka diskusija“, u kojoj su učestvovali gotovo svi dele-

\footnotetext{
${ }^{46}$ Isto, 8. avgust 1924.

${ }^{47}$ Orjuna, 20. septembar 1924.

${ }^{48}$ Seja glavnega odbora $v$ Ljubljani, Orjuna, 4. april 1925.
} 
gati, naročito dr Leontić, koji je u svom „dveurnem“ (dvočasovnom) govoru iscrpno predstavio odnos „Orjune" prema programima i taktikama stranaka. „Brat" Bartulović je „specijalno obdelal razmerje jugoslavenskega nacionalizma" u odnosu na nacionalističke pokrete u inostranstvu. Poslije Bartulovića govorili su „braća“ Jevđević, Levstik, vojvoda Trifunović, dr Bulat i drugi. Izraženo je uvjerenje da je Orjuna „jedinstvena i u mišljenju i osjećanju ('v čutenju')“, i da je njen rad „kontinuitet direktnog uticaja ideologije i dela predratne nacionalističke omladine“. Na kraju je zaključeno da Orjuna i nadalje ostane nezavisna organizacija jugoslovenskog pokreta, a Direktoriju je povjereno da formuliše stajalište Orjune prema aktuelnim pitanjima, uz pomoć oblasnih odbora, koji su trebali neophodni materijal poslati Direktorijumu u Split. ${ }^{49}$

Protivnici Orjune (klerikalci i komunisti) zalagali su se za njeno ukidanje, sa argumentima da i bez nje ima previše jugoslavenskih nacionalnih organizacija. Na njihovo pitanje „Čemu Orjuna?“, orjunaši su odgovarali da "danas nema potpune avangarde jugoslavenskog nacionalizma" i da samo sokolstvo nije dovoljno. Zaključili su da Orjuna ima pored Sokolstva svoj rezon d'etr, da te dvije organizacije nisu konkurentske i da jedna drugu dopunjuju. ${ }^{50}$

U štampi je sve više pojačavana kampanja protiv Orjune, pa čak i kampanja Pribićevićeve Samostalne demokratske stranke, naročito od vremena kad je ljubljanska Orjuna pisala o sukobu Leontić-Pribićević. Vodstvo Pribićevićeve SDS i njihova štampa (Reč, Riječ, Jutro), koja je nekad nastupala sa integralno-jugoslavenskih pozicija, okrenula se protiv Orjune. "Samostalne demokrate" su odjednom zamjenjivale Orjunu sa HANAO, SRNAO, MUNAO, SLONAO. Na sve napade orjunaši su odgovarali da je Orjuna organizacija Nacije, a ne SDS, dok se njezino „djelo za Naciju“ razlikovalo od svih nacionalno „uskogrudih partija“, pa tako i od SDS. ${ }^{51}$

Naročito je bila intenzivna propagandna borba između klerikalne Koroščeve SLS i Orjune, koja je u svojim „odbrambenim nastupima“ stalno isticala antijugoslavenstvo SLS i patera Korošeca: „SLS je danas jedina stranka koja svuda i u svakoj prilici svoje katoličke ljubaznosti propagira neprijateljstvo protiv jugoslavenskih nacionalista, i uvijek prije svega protiv Orjune. Ako se pronađe kod nesretnika, koji je nepromišljeno sam okončao svoj život, legitimacija Orjune, kriči Slovenec o tajnoj Orjuni i poziva u pomoć državnu vlast. SLS ih predstavlja kao raspuštene orjunaše. Ali Orjuna postoji, ima svoje vrhovno vodstvo u Splitu i organizacije po cijeloj državi. Orjuna je javna i od državnih vlasti priznata organizacija, te nijedna

\footnotetext{
${ }^{49}$ Isto.

${ }^{50}$ M. Kovačić, Orjuna in Sokolstvo, Orjuna, 4. april 1925.

${ }^{51}$ Vodstvu SDS, Orjuna, Ljubljana, 5. januarj 1926.
} 
državna vlast ne može zabranjivati članstvo u toj organizaciji. Ako ne smemo biti članovi raspuštenih organizacija ljubljanske oblasti, mi smo članovi drugih neraspuštenih organizacija, i kao članovi vršimo svoje dužnosti. 'Ljubljanskega oblastnega odbora in drugih organizacij ljubljanske oblasti ni več po raspustu, so pa tu in bodo vedno nacionalisti - člani organizacij izven ljubljanske oblasti'. Stvar je tih izvanljubljanskih organizacija kako će urediti svoje odnose prema nama, raspuštenim orjunašima. Pravni položaj, koji je nastao protivzakonitim raspustom organizacija ljubljanske oblasti, je prirodno apsurdan. Sva ta apsurdnost se je pokazala u času otkrića spomenika Kralju Oslobodiocu u Kranju. Orjunaši izvan ljubljanske oblasti, smeju nositi svoje kroje, smeju nastupati javno. Međutim, čim su stupili na teritorij ljubljanske oblasti postali su bespravna raja, žandarmerija ih je lovila, i trgala im obleke $\mathrm{z}$ njih teles. Zahvaljujući samo disciplini orjunaša nije došlo do težih ekscesa koji bi osramotili našu državu pred cijelim svetom“.

Zbog teškog položaja Orjune u ljubljanskoj oblasti, u nastavku napisa iz lista Orjuna istaknuto je slijedeće: „Položaj je približno jednak kot bi nastal, če bi katerikoli sreski poglavar za svoj srez prepovedal Sokolom, Orlom ili na pr. Marijinim devicam svako društveno desovanje in vsak javni nadstup, recimo vsled dejstva da so se Orli ali Sokoli njegovog sreza med seboj stepli ali pa da so Marijine device opljuvale in opsovale bodisi poglavarja samega ali njegove varnostne organe. Ni menda človeka ki bi se ne smejal taki odredbi politične oblasti, raspust Orjune v ljubljanski oblasti je popolnoma enakovredan čin v pravnem oziru nemogoč oziroma mogoč le $\mathrm{v}$ srečni Jugoslaviji, ki je ne upravlja enotna vlada po enotnih, za vso državo veljavnih vidikih, marveč jo upravljajo le politične partije in klike, ki si po vsakokratni sestavi vlade dele državo v razna strankarska področja, ki jih nato upravljajo in osrečujejo le z vidika partije. Sicer pa: hvala lepa za raspust in Vas, gospodje od SLS le prosimo, da raspušćate še naprej. Komunizam opstaje uprkos Obznani“".

U mariborskoj oblasti, u kojoj je Orjuna djelovala legalno, održana je četvrta redovna oblasna skupština, kojim povodom su priređene ovacije zastupnicima raspuštene ljubljanske orjunaške oblasti. U Slovenecu su neprestano izlazili „krvavi članki proti Orjuni“, kao stavovi oficijelnog klerikalnog izvora. Osnovni refren članaka bila je konstatacije da Orjunu treba raspustiti i u Mariborskoj oblasti. U časopisima je osvanula vijest o dr Irgoliču da je „že zapt, čeprav je še danes na slobodi“. Na pritisak političke vlasti policija je počela zatvarati orjunaše, "kar en mase in je sedaj v zaporih mariborskega sodišča okoli 10 orjunašev“, među njima i oblasnog čelnika dr Reju. Uzroci hapšenja bili su nepoznati, ali je zaključeno da je „teror velikanski““. ${ }^{53}$

${ }^{52}$ Tajna Orjuna, Orjuna, Ljubljana, 19. marc 1927.

${ }^{53}$ Aretacija Orjunaša, Orjuna, Ljubljana, 16. april 1927. 
U Zagrebu je 10. aprila 1927. održan „III kongres svih Orjuna“, koji je imao osnovni cilj reorganizaciju Orjune. Geslo slovenačke Orjune i dalje je bilo „Orjuna iznad svega“, i drugo geslo „Za Naciju“, u potpisu „Marko, Veliki čelnik“. ${ }^{54}$ Četvrti kongres svih Orjuna održan je ponovo u Zagrebu, 9. oktobra 1927. godine. Ljubljanska Orjuna je izvjestila da se u Zagrebu 9. oktobra održavao dugo očekivan kongres na kojem je trebalo „potegniti črto pod dosezanje aktivne in pasivne postavke dela Orjune in naznačiti smernice bodočega udejstvovanja organizacije“. Kongres je otvorio veliki čelnik svih orjuna, brat Marko Kranjec koji je upozorio brojne prisutne delegate „na resnost in globino pomena kongresa“, od kojega zavisi buduća „usoda nam vsem tako drage in ljube Orjune“. Pošto je istakao opasan momenat $u$ kojem se nalazi zemlja zbog stranih neprijatelja, koje predvodi „zakleta sovražnica“ Italija, koja se ne ustručava ni najkriminalnijih akata da bi uklonila Orjunu, prešao je na iscrpan izvještaj o neophodnoj reorganizaciji Orjune. Orjuna je spremna i sposobna za daljnji samostalni opstanak - bila je osnovna poruka. ${ }^{55}$

Na kongresu su govorili i predsjednik Orjune Beograda dr Miodrag Dimitrijević, potom delegat sjevernodalmatinske Orjune „brat" Vladko Maček, koji je govorio o potrebi prečišćenja Orjune, upozorio na velike tradicije Orjune i veličinu žrtve, „koja od nas zahtijeva samo jedno: - Pobjediti ili umrijeti“. Njegov mladalački govor oduševio je sve prisutne, ali je Marko Kranjec upozorio da „moramo Orjunaši pričeti že enkrat z realističnim gledanjem na svet in razmere take kakšne so. Z našim do neba segajočnim idealizmom in fanatizmom zadivljujemo sicer mnoge, ali masa ostaja flegmatična in izreka svoje poverjenje še vedno kova dr Lazice Markovića in pušća na cedilu njene prave prijatelje in borce, kot so dr Krulj in mnogi drugi, ko so zaman pričakovali, da se je narod po dosedanjim tegobnih izkušenjah izmodrili“".

Najviše debate izazvalo je pitanje odnosa Orjune prema političkim strankama: „Danas je položaj takav da treba računati s političkim stanjem, i konačno treba obračunati s frazom o van i nadpartijskim djelovanjem Orjune... Orjunu kao organizaciju ne treba depolitizovati in povleči iz sedanjeg vrtinca, njeni člani pa naj vstopijo v jugoslovensko orijentirane partije, koji treba u interesu nacije i države pošteno infiltrirati s orjunaštvom.... ${ }^{56}$ Orjuna se ipak polako gasila zbog sve češćih regionalnih zabrana, a njeni bivši članovi ulazili su u političke stranke jugoslavenske orijentacije, koje su, $\mathrm{u}$ vremenu prije pojavljivanja Jugoslovenske nacionalne stranke 1932, bile u izraženom nestajanju. Poslije sve jačih progona orjunaša od strane slove-

\footnotetext{
${ }^{54}$ Isto.

${ }^{55}$ IV kongres vseh Orjun v Zagrebu, Orjuna, 15. oktobar 1927.

${ }^{56}$ Isto.
} 
načkih klerikalaca i „radićevaca“ u ljubljanskoj i zagrebačkoj oblasti 1927/28. godine, orjunaške organizacije su jedino opstale u Beogradu, Novom Sadu (oblasni odbor), Mariboru i sa Direktorijumom u ,jugoslavenskom" Splitu. ${ }^{57}$

Slabljenjem i gašenjem Orjune Bartulović se pasivizirao u organizaciji i okretao radu u jugoslavenskoj nacionalnoj organizaciji „Jadranska straža“, naročito na publicističkim i uredničkim poslovima u njenom listu Jadranska straža. Iako je bila ekskluzivna integralno-jugoslavenska organizacija, Orjuna je potpala pod udar Zakona o zaštiti javne bezbednosti i poretka u državi od 6. januara 1929. godine. Tako je Uprava Grada Beograda u januaru 1929. dekretom zabranila djelovanje Orjune, u skladu sa novim šestojanuarskim zakonodavstvom o zabrani djelovanja vjerskih i plemenskih organizacija.

Tradicionalno prijateljske odnose sa slovenačkim liberalima, preko jugoslavenskih Sokola i „nekadašnje“ Orjune, Bartulović je i dalje održavao preko organizacija (odbora) „Jadranske straže“. ${ }^{58} \mathrm{Na}$ „impozantnim svečanostima" i manifestacijama "Za naše more" u Ljubljani on je bio uvažen gost. U Ljubljani je, naime, od 5. do 8. septembra 1935. održan kongres „Jadranske straže“ uz „velike manifestacije na rođendan Nj. V. kralja Petra II“. Uoči kongresa očekivalo se da će „rođendan $\mathrm{Nj}$. V. Kralja, najvišeg zaštitnika Jadranske straže“, Ljubljana vidjeti „u znamenju manifestacija, osobito omladine u počast svog Najvišeg Druga“. ${ }^{59} \mathrm{U}$ čast kraljevog rođendana i „Jadranske straže“ biskup ljubljanski Rožman služio je „zahvalnu službu božju“, a nakon toga izvršeno je osvećenje i razviće zastave „Jadranske straže - Ljubljana“, koju je podario i istoj kumovao kralj Petar II. Svečanom činu prisustvovali su školska mladež, brojna društva i brojni članovi podmlatka „Jadranske straže“ iz „cijele države“. Poslije manifestacija gradom je defilovala velika povorka. U velikoj dvorani sokolskog doma na Taboru održana je akademija pod nazivom „Slovenija i Jadran u pjesmi i riječi“ uz sudjelovanje akademskog pjevačkog kora i „predavača“ književni-

${ }^{57}$ Almanah Kraljevine Srba, Hrvata i Slovenaca, svezak III, deo IV, Zagreb 1927/28, 252.

58 Jadranska straža je osnovana u trenutku kada je „Promicateljni odbor“ sastavio nacrt pravila i predao ih Pokrajinskoj upravi za Dalmaciju na odobrenje, koja ih je odobrila 4. februara 1922. godine. „Promicateljni odbor“ je odlučio sazvati prvu javnu Ustavotvornu skupštinu udruženja za 19. februar 1922. u Splitu, na kojoj je izabrana prva uprava na čelu sa predsjednikom Jurajem Biankinijem, potpredsjednikom dr Ivom Tartaljom i sekretarom prof. Silvijem Alfirevićem. Moto organizacije bio je „Čuvajmo naše (jugoslavensko) more“. Prestolonasljednik Petar Karađorđević u septembru 1923. prihvatio se pokroviteljstva nad organizacijom. Društveni znak je bio Markov topuz, izvučen napola iz mora, koji je prema narodnoj legendi zamislio i izradio umjetnik Tomazeo. - Almanah Kraljevine Srba, Hrvata i Slovenaca, svezak III, deo 7-9, VII, Zagreb, 1927/28, 191.

${ }^{59}$ Narodne novine, Zagreb, 3. septembar 1935. 
ka Nike Bartulovića iz Beograda, Dragoljuba Todorčevića iz Splita i inž. Milana Šukljea iz Ljubljane.

Bivši slovenački orjunaši i slovenački četnici, kao u doba pune orjunaške snage, ostali su vjerni beogradskom Udruženju četnika „Za čast i slavu Otadžbine“. Udruženje je organizaciono jačalo i širilo mrežu organizacija po zapadnim krajevima Jugoslavije. Tako su 7. novembra 1932, u prisustvu brojne omladine i naročito „visokoškolaca“, jugoslavenski nacionalisti (Slovenci) osnovali pododbor Udruženja u Ljubljani. Sastanak je otvorio Fran Horvatin i pri tom pozdravio sekretara glavnog odbora Udruženja četnika Topalovića iz Beograda, zatim predstavnika dalmatinskih četnika Brčića, predsjednika zagrebačkog pododbora četnika Lukatela, kao i zastupnika Narodne odbrane dr Capudera iz Slovenije. Za predsjednika ljubljanskog pododbora Udruženja četnika izabran je V. Arko, a za potpredsjednika Fran Horvatin. ${ }^{60}$

Poslije ubistva kralja Aleksandra I 1934. godine, i stupanja na čelne državne pozicije namjesnika kneza Pavla i vlade Milana Stojadinovića u ljeto 1935 , nastali su teški dani za jugoslavenske nacionaliste i jugoslavenske nacionalne organizacije jer se državna politika, pod britanskim uticajem dezintarizacije Jugoslavije, kretala u pravcu jugoslavenskog „troplemenog federalizma“. Jugoslavenski Sokoli, bivši „orjunaši“, pripadnici Jadranske straže i jugoslavenski Četnici su bili na udaru nove vladavinske „jerezine“ (JRZ) političke kombinacije, teško odoljevajući napadima Koroščevih rimokatoličkih klerikalaca i hrvatskog vjerskog i političkog vodstva. ${ }^{61}$

Nikola Žutić

NIKO BARTULOVIĆ AND THE YUGOSLAV ORIENTED SLOVENES

\section{Summary}

The author provides the reconstruction of the Yugoslavism phenomenon in western parts of the Kingdom of Yugoslavia, inhabited by the Roman Catholic population. It was rooted in activities of the Dalmatian and Slovenian revolutionary national-liberal pro-Yugoslav youth. Those integral Yugoslavian groups were base for the creation of the several Yugoslav organizations such as ORJUNA, the Yugoslav Soko, the Jadran Guard and Yugoslav Chetniks. The author devotes the main attention to Niko Bartulović, the writer, which belonged to such political and cultural circles in the city of Split. Bartulović was one of the prominent Yugoslav revolutionaries, accused during the First World War by the Austro/Hungarian authorities and later when the Kingdom of Yugoslavia was formed one of the main promoters of such pan-Yugoslav oriented organizations.

${ }^{60}$ Jutro, Ljubljana, 9. novembar 1932.

${ }^{61}$ Vidjeti: N. Žutić, Sokoli, Beograd 1991; Todor Stojkov, Vlada Milana Stojadinovića, Beograd 1986; N. Žutić, Niko Bartulović - rimokatolik četnik, Beograd 2010. 